\title{
Carbapenem-resistant enterobacteriacae: a challenge for early detection and infection control
}

\author{
C Fankhauser ${ }^{*}$, A Cherkaoui, G Renzi, M Abbas, J Schrenzel, D Pittet, S Harbarth \\ From International Conference on Prevention \& Infection Control (ICPIC 2011) \\ Geneva, Switzerland. 29 June - 2 July 2011
}

\section{Introduction / objectives}

In 2009, in response to the threat of emerging carbapenem-resistant Enterobacteriaceae, an alert system was introduced at Geneva University Hospitals.

\section{Methods}

The alert system detected patients harboring carbapenemase-producing strains as KPC or non-KPC. Referrals from other hospitals were screened on admission for the presence of multiresistant organisms, and put under contact control precautions if positive.

\section{Results}

Between October 2009 - January 2010, we identified 1 imported case of KPC (origin, Southern Italy) and 3 cases of NDM-1 producing Enterobacteriaceae, transferred from hospitals in India (1), Pakistan (2) and Serbia/ France(3).

Patient 1- on admission digestive carrier of E. coli bla $a_{\mathrm{NDM}-1}$.

Patient 2- digestive carrier of P. mirabilis $b l a_{\mathrm{NDM}-1}$ detected after extended hospitalization and antibiotic therapy

Patient 3- hospitalized in Serbia and France, with $K$. pneumonia bla $a_{\mathrm{NDM}-1}$ urinary tract infection on admission.

All 3 patients were carriers of other multiresistant, Gram-negative bacteria on admission. The NDM-1 molecular identification was made retrospectively in October 2010. Patient 4 was admitted for elective surgery, without prior history of hospitalization. A urine culture yielded K. pneumoniabla $a_{\mathrm{KPC}-2}$. The patient was put under strict contact precautions; but developed a surgical site infection

University of Geneva Hospitals, Geneva, Switzerland with treatment challenges related to dose finding, availability, toxicity of antibiotics. No secondary cases were found due to early screening and preemptive isolation.

\section{Conclusion}

The threat of carbapenemase-producing strains underlines the need for early detection, implementation of control measures and surveillance, which needs constant updating. The laboratory alert system focused on KPC but ignored initially the NDM-1 threat.

\section{Disclosure of interest}

None declared.

Published: 29 June 2011

doi:10.1186/1753-6561-5-S6-P142

Cite this article as: Fankhauser et al:: Carbapenem-resistant

enterobacteriacae: a challenge for early detection and infection control. BMC Proceedings 2011 5(Suppl 6):P142.

Submit your next manuscript to BioMed Central and take full advantage of:

- Convenient online submission

- Thorough peer review

- No space constraints or color figure charges

- Immediate publication on acceptance

- Inclusion in PubMed, CAS, Scopus and Google Scholar

- Research which is freely available for redistribution

Submit your manuscript at www.biomedcentral.com/submit
() Biomed Central

\section{Biomed Central}

(c) 2011 Fankhauser et al; licensee BioMed Central Ltd. This is an open access article distributed under the terms of the Creative Commons Attribution License (http://creativecommons.org/licenses/by/2.0), which permits unrestricted use, distribution, and reproduction in any medium, provided the original work is properly cited. 